\title{
Metabolites able to predict uterine diseases in crossbred dairy cows during the transition period
}

\section{Metabólitos capazes de predizer enfermidades uterinas em vacas leiteiras mestiças no período de transição}

\author{
Erick Daibert ${ }^{1}$; Paula Batista de Alvarenga ${ }^{1}$; Amanda Lima Rezende ${ }^{1}$; \\ Nádia Simarro Fagundes ${ }^{2}$; Barbara Cristina Krüger $^{3}$; Ricarda Maria dos Santos ${ }^{4}$; \\ Antonio Vicente Mundim ${ }^{5}$ J João Paulo Elsen Saut ${ }^{6 *}$
}

\begin{abstract}
This study aimed to identify possible metabolites able to predict puerperal uterine diseases in crossbred dairy cows (Holstein $\mathrm{x}$ Gir) in the transition period. We hypothesized that, as what has been observed for Holstein cows, a negative energy balance (NEB) may increase the incidence of uterine diseases. Thirtyfour lactating crossbred cows $(1 / 2 \mathrm{HG}, 1 / 4 \mathrm{HG}, 3 / 4 \mathrm{HG}$, and $5 / 8 \mathrm{HG})$ were evaluated during prepartum $(-60 \mathrm{~d}$ and $-30 \mathrm{~d})$, calving, and postpartum $(+14 \mathrm{~d},+21 \mathrm{~d}$, and $+35 \mathrm{~d})$ periods, being divided into two groups (with and without uterine diseases). NEB evaluations were based on the concentrations of non-esterified fatty acids (NEFA) and beta-hydroxybutyrate (BHBA) at calving and 14 days postpartum. Nearly 1/3 of the crossbred cows presented an NEB, characterized by a significant increase in NEFA with no BHBA increase; however, it was less intense than that observed in Holstein cows during the transition period. There was a significant difference between cows with and without uterine diseases in NEFA and calcium concentrations at partum, as well as body condition score (BCS) during prepartum. In conclusion, the occurrence of uterine diseases during the transitional period is related to the BCS in the prepartum period, besides serum NEFA and calcium concentrations at partum.
\end{abstract}

Key words: Body condition score. NEFA. Endometritis. Metritis.

\section{Resumo}

O objetivo do estudo foi identificar possíveis metabólitos no período de transição capazes de predizer a ocorrência de enfermidades uterinas puerperais em vacas leiteiras (Holandês X Gir). A hipótese foi de que, semelhante ao observado em vacas Holandesas, o balanço energético negativo (BEN) aumentaria a incidência de enfermidades uterinas. Foram utilizadas 34 vacas lactantes com variação entre $1 / 2 \mathrm{HG}$, $1 / 4 \mathrm{HG}, 3 / 4 \mathrm{HG}$ e $5 / 8 \mathrm{HG}$ de composição genética. Os momentos avaliados foram estabelecidos como pré-

\footnotetext{
${ }^{1}$ Mestres em Ciências Veterinárias, Large Animal Health Laboratory, LASGRAN, Pesquisadores, Universidade Federal de Uberlândia, UFU, Uberlândia, MG, Brasil. E-mail: erick_vett@yahoo.com.br; paulabatista_alvarenga@hotmail.com; amanda rezende@hotmail.com

2 Dr $^{\mathrm{a}}$ em Ciências Veterinárias, Large Animal Health Laboratory, LASGRAN, Pesquisadora, UFU, Uberlândia, MG, Brasil. E-mail: nadia_simarro@yahoo.com.br

3 Médica Veterinária, Large Animal Health Laboratory, LASGRAN, Discente de Mestrado, UFU, Uberlândia, MG, Brasil. E-mail: barbarackruger@yahoo.com.br

${ }^{4}$ Prof $^{\mathrm{a}}$, Departamento de Reproduação Animal, Prof ${ }^{a}$, UFU, Uberlândia, MG, Brasil. E-mail: ricarda.santos@.ufu.br

5 Prof., Departamento de Patologia Clínica Animal, UFU, Uberlândia, MG, Brasil. E-mail: antoniomundim@ufu.br

6 Prof., Departamento de Clínica e Cirurgia de Grandes Animais, Large Animal Health Laboratory, LASGRAN, Prof., UFU, Uberlândia, MG, Brasil. E-mail: jpsaut@.ufu.br

* Author for correspondence
} 
parto (-60d e -30d), parto e pós-parto $(+14 \mathrm{~d},+21 \mathrm{~d}$ e $+35 \mathrm{~d})$ e as fêmeas divididas em dois grupos, com e sem enfermidades uterinas. O BEN foi estabelecido com base nas concentrações de ácidos graxos nãoesterificados (NEFA) e beta-hidroxibutirato (BHBA) no parto e 14 dias pós-parto. Observou-se que cerca de $1 / 3$ das vacas mestiças passaram por BEN caracterizado por aumento significativo de NEFA e sem aumento de BHBA, porém em intensidade menor do que o observado em vacas Holandesas. Verificouse diferença significativa do escore de condição corporal (ECC) no pré-parto e das concentrações de NEFA e de cálcio no parto, entre vacas com e sem enfermidades uterinas. Conclui-se que o ECC no préparto e as concentrações de NEFA e cálcio no parto se relacionam com a ocorrência de enfermidades uterinas.

Palavras-chave: Escore de condição corporal. NEFA. Endometrite. Metrite.

\section{Introduction}

The genetic improvement achieved by crossing Zebu and European breeds has allowed a higher productivity per animal in dairy cattle, which generates greater challenges in peripartum. During this period, the energy demand increases for fetal nutrition and lactogenesis initiation, coinciding with a reduction in dry matter intake (JUCHEM et al., 2004, CAMPOS et al., 2005). In this phase, cows enter a state of negative energy balance (NEB) that is characterized by a reduction of plasmatic glucose concentration and mobilization of corporal reserves for additional energy acquisition (DRACKLEY, 1999; KIMURA et al., 2002; ACCORSI et al., 2005).

Depending on the intensity of this imbalance, dairy cow performance and health may be compromised in the postpartum period, as there is a relationship between energy deficiency and immunosuppression (HAMMON et al., 2006). Lacetera et al. (2005) observed a decline in body condition score (BCS) of cows with intense lipomobilization and a consequent increase in nonesterified fatty acids (NEFA) around calving, which impaired defense cell functions.

Quantifying the metabolites stored in body reserve tissues enables a proper monitoring of cows at the onset of lactation when demands for energy, protein, and minerals increase. In addition, it allows the diagnosis of metabolic disorders and nutritional deficiencies, as well as the investigation of health problems and productive performance (LEBLANC et al., 2006; DUFFIELD; LEBLANC, 2009).

Ospina et al. (2010) demonstrated the association of critical thresholds for lipid metabolites with an increased risk of postpartum disease. NEFA concentrations above $0.3 \mathrm{mEq} \mathrm{L}^{-1}$ in prepartum cows and above $0.6 \mathrm{mEq} \mathrm{L}^{-1}$, together with ketone bodies - mainly beta-hydroxybutyrate (BHBA), above $10 \mathrm{mg} \mathrm{dL}^{-1}$ in postpartum animals denote a higher risk of developing retained placenta and metritis. Additionally, early post-partum hyperketonemic cows have a higher risk of developing subclinical endometritis (DUBUC et al., 2010). According to Chapinal et al. (2012), high concentrations of NEFA and BHBA, or low of calcium, during the early postpartum period are associated with a higher risk of abomasal displacement, milk production decrease, and reduced pregnancy rates at the first service.

In the present study, we aimed to identify metabolites capable of predicting postpartum uterine diseases in crossbred dairy cows (Holstein X Gir) in the transition period; this crossbreeding represents most of the Brazilian dairy herd (FACÓ et al., 2002) and accounts for $70 \%$ of all milk production (NOVAES et al., 2003). Therefore, we hypothesized that, as what has been identified in Holstein cows, NEB and hypocalcemia could increase the incidence of postpartum uterine diseases. 


\section{Material and Methods}

Local, installations, and animals

The study was conducted in a commercial farm located in Uberlandia, in the southwest of Minas Gerais State-Brazil, with a local climate classified as Aw (KÖPPEN, 1948). Thirty-four crossbred lactating cows (Holstein/Gir) were assessed. These animals had a varying genetic composition ( $1 / 4 \mathrm{HG}, 1 / 2 \mathrm{HG}, 5 / 8 \mathrm{HG}$, and $3 / 4 \mathrm{HG}$ ), being calved between November 2014 and July 2015. Average body condition score (BCS) at parturition was 3.24 \pm 0.29 , and the herd average daily milk yield was $24.53 \pm 4.52$ liters/cow/day. The Ethics Committee for Animals Use (CEUA) of the Federal University of Uberlandia approved the project (protocol no. 212/13).

At 60 days pre-partum, the animals were dried and placed in Urochloa decumbens pasture. At 30 days pre-partum, an anionic ration (48\% sorghum, $42 \%$ soybean meal, $9 \%$ anionic nucleus, and $1 \%$ urea) and corn silage were offered to the animals up to calving. In the postpartum period, the cows remained confined and received a diet with corn silage, barley, and concentrate prepared at the farm (sorghum $65 \%$, soybean meal $30 \%$, premix for lactation $2.5 \%$, urea $1.25 \%$, and limestone $1.25 \%$ ), besides a mineral supplementation. Throughout the entire period, the animals had free access to a shaded area and water.

\section{Experimental design}

The animals were followed during pre-partum (-60d and $-30 d)$, partum and postpartum $(+14 d,+21 d$ and $+35 d)$. Two groups were formed: a) control cows without any uterine disease at postpartum; b) uterine infection: cows diagnosed with at least one postpartum uterine disease. General physical examination and diagnosis of uterine diseases were performed at each moment of evaluation. The diagnosed uterine diseases were placenta retention, metritis, clinical endometritis, and subclinical endometritis.

\section{Sampling and analyses}

Samples were collected at six pre-defined moments for physical examination and uterine disease diagnoses. Blood samples were collected after the first milking in the morning by puncture of the median caudal vein into tubes containing coagulation gel, using a vacuum collection system. These samples were refrigerated and sent to the Laboratory for Clinical Analysis of the Veterinary Hospital at UFU for analyses.

The biochemical profile was determined using a ChemWell® multi-channel automatic analyzer (Awareness Technology Inc., Palm City, USA) at $37^{\circ} \mathrm{C}$. Proteins (total protein, albumin, and globulin), minerals (calcium, phosphorus, and magnesium), enzymes (aspartate aminotransferase - AST, creatine kinase - CK, gamma-glutamyltransferase - GGT), and energetic metabolites (cholesterol, triglycerides and high-density lipoproteins - HDL) were analyzed by Labtest ${ }^{\circledR}$ diagnostic kits (Labtest Diagnóstica AS, Lagoa Santa, Brasil). The serum concentrations of very low-density lipoprotein $[(\mathrm{VLDL})=]$ and low-density lipoproteins $[(\mathrm{LDL})=]$ were calculated based on Friedewald's formula (FRIEDEWALD et al., 1972). While BHBA and NEFA serum concentrations were determined using the Randox ${ }^{\circledR}$ Kit (Randox Laboratories Ltd, Crumlin, UK).

The metabolic profile reference values of cows during the transition period were those proposed by Smith (2009). Negative energy balance (NEB) was defined based on the concentrations of NEFA and BHBA at parturition and 14 days postpartum (DPP), with critical levels $\geq 0.6 \mathrm{mEq} \mathrm{L}^{-1}$ for NEFA and $\geq$ $10 \mathrm{mg} \mathrm{dL}^{-1}$ for BHBA, according to Ospina et al. (2010). 


\section{Classification and treatment of uterine diseases}

For uterine disease classification, we considered the following parameters:

a) Placenta retention: when fetal membranes were not released within $12 \mathrm{~h}$ postpartum (FERREIRA, 2010).

b) Metritis: when cows presented distended uterus and purulent and fetid secretion between the first and second week postpartum, with or without systemic signals (SHELDON et al., 2009).

c) Clinical Endometritis: cows showing intrauterine fluid (IUF) and mucopurulent or purulent secretion in the Metricheck exam 35 DPP. IUF was detected using a transrectal ultrasound (DP 2200Vet; Mindray ${ }^{\circledR}$, China) and a 5-10 $\mathrm{MHz}$ transductor. Vaginal secretion was assessed with a Metricheck device on a 3-point scale (0-3), according to Williams et al. (2005).

d) Subclinical Endometritis: cows with a percentage of polymorphonuclear cells (PMN) above $10 \%$, in the absence of clinical endometritis (SHELDON et al., 2006), at 35 DPP. The material was collected using an adapted endometrial cytobrush (KASIMANICKAM et al., 2004), being subsequently deposited onto glass slides, and stained with panoptic rapid staining method (Laborclin ${ }^{\circledR}$, Pinhais, Brazil).

Treatment for placental retention included the administration of two doses of $20 \mathrm{mg} \mathrm{kg}^{-1} 20 \%$ oxytetracycline - OTC-LA (Ourofino ${ }^{\circledR}$, Cravinhos, Brasil) intramuscularly. In cases of endometritis, three doses of $1 \mathrm{mg} \mathrm{kg}^{-1}$ ceftiofur chloride at $10 \%$ (Ourofino ${ }^{\circledR}$, Cravinhos, Brasil) were administered every 24 hours. BCS was evaluated at all times and classified as between 1 and 5, with subunits of 0.25 (EDMONSON et al., 1989).

\section{Statistics}

The statistical analyses were performed by GraphPad Prism software version 6.03 (GraphPad Software Inc., La Jolla, USA). The collected data were first tabulated in spreadsheets using Microsoft Excel and presented as an average \pm standard deviation. All the data of biochemical analyses underwent variance analysis (two-way ANOVA) to determine interactions and differences between groups and times; if significant, a posttest of Bonferroni was conducted. BCS was used to compare the evaluated times using the nonparametric test of Friedman, while the comparisons between groups and within times were made by the non-parametric test for paired samples of Wilcoxon. The difference between uterine disease frequencies with and without NEB was assessed by the chisquared test. The significance level for all tests was $\mathrm{p}<0.05$.

\section{Results}

The clinical evaluation of the 34 cows showed an incidence of $41.2 \%(14 / 34)$ of postpartum uterine diseases, distributed in 5.9\% (2/34) for placenta retention, $20.6 \%$ (7/34) for metritis, $11.8 \%(4 / 34)$ for clinical endometritis, and $32.3 \%$ (11/34) for subclinical endometritis; the same cows showed one or more uterine disorders in postpartum. The NEB was identified in $35.3 \%(12 / 34)$ of the evaluated cows, and there was no tendency for these animals to present a greater incidence of uterine infections. The relationship between NEB and the occurrence of placental retention, metritis, and clinical or subclinical endometritis was not verified (Table 1). 
Table 1. Energy balance of crossbred dairy cows (Holstein/Gir) with uterine diseases under an intensive production system, Uberlandia - Minas Gerais State, Brazil.

\begin{tabular}{cccccc}
\hline Energy Balance & $\begin{array}{c}\text { Placental } \\
\text { Retention }\end{array}$ & Metritis & $\begin{array}{c}\text { Clinical } \\
\text { Endometritis }\end{array}$ & $\begin{array}{c}\text { Subclinical } \\
\text { Endometritis }\end{array}$ & $\begin{array}{c}\text { Uterine } \\
\text { Diseases }\end{array}$ \\
\hline Positive & $0.0 \%(0 / 22)$ & $13.0 \%(3 / 22)$ & $8.7 \%(2 / 22)$ & $30.4 \%(7 / 22)$ & $34.8 \%(8 / 22)$ \\
Negative & $16.7 \%(2 / 12)$ & $33.3 \%(4 / 12)$ & $16.7 \%(2 / 12)$ & $33.3 \%(4 / 12)$ & $50.0 \%(6 / 12)$ \\
p-value & 0.1109 & 0.1904 & 0.5941 & 1.000 & 0.4769 \\
\hline
\end{tabular}

Note: Placental Retention was diagnosed according to Sheldon et al. (2009) and Williams et al. (2005); Metritis as Sheldon et al. (2009); Clinical Endometritis as Williams et al. (2005); Subclinical Endometritis as Kasimanickam et al. (2004). The Chi-squared test at 5\% significance was used for statistical analysis. Crossbred dairy cows (Holstein/Gir) had an average daily milk yield of $24.5 \mathrm{~kg}$.

Regarding BCS, there was a difference between the evaluated groups at the first evaluation (-60d), when the average of cows with uterine infections $(3.6 \pm 0.2)$ was higher than that of the control group $(3.3 \pm 0.1)$ (Figure 1A). Additionally, on the day of calving, these infected cows presented the highest NEFA $\left(0.88 \pm 0.65 \mathrm{mEq} \mathrm{L} \mathrm{L}^{-1}\right)$, being significantly above those of healthy animals (Figure
1B). However, the serum concentrations of BHBA were similar between both groups at all measured times (Figure 1C). The levels of total, HDL, LDL and VLDL cholesterol and triglycerides were determined based on the evaluation of energy metabolism (Figures 1 D-H). For these metabolites, no difference between healthy and infected animals was detected. 
Figure 1. Energy profile of crossbred dairy cows (Holstein/Gir), with or without uterine diseases, under an intensive production system, Uberlandia - Minas Gerais State, Brazil.

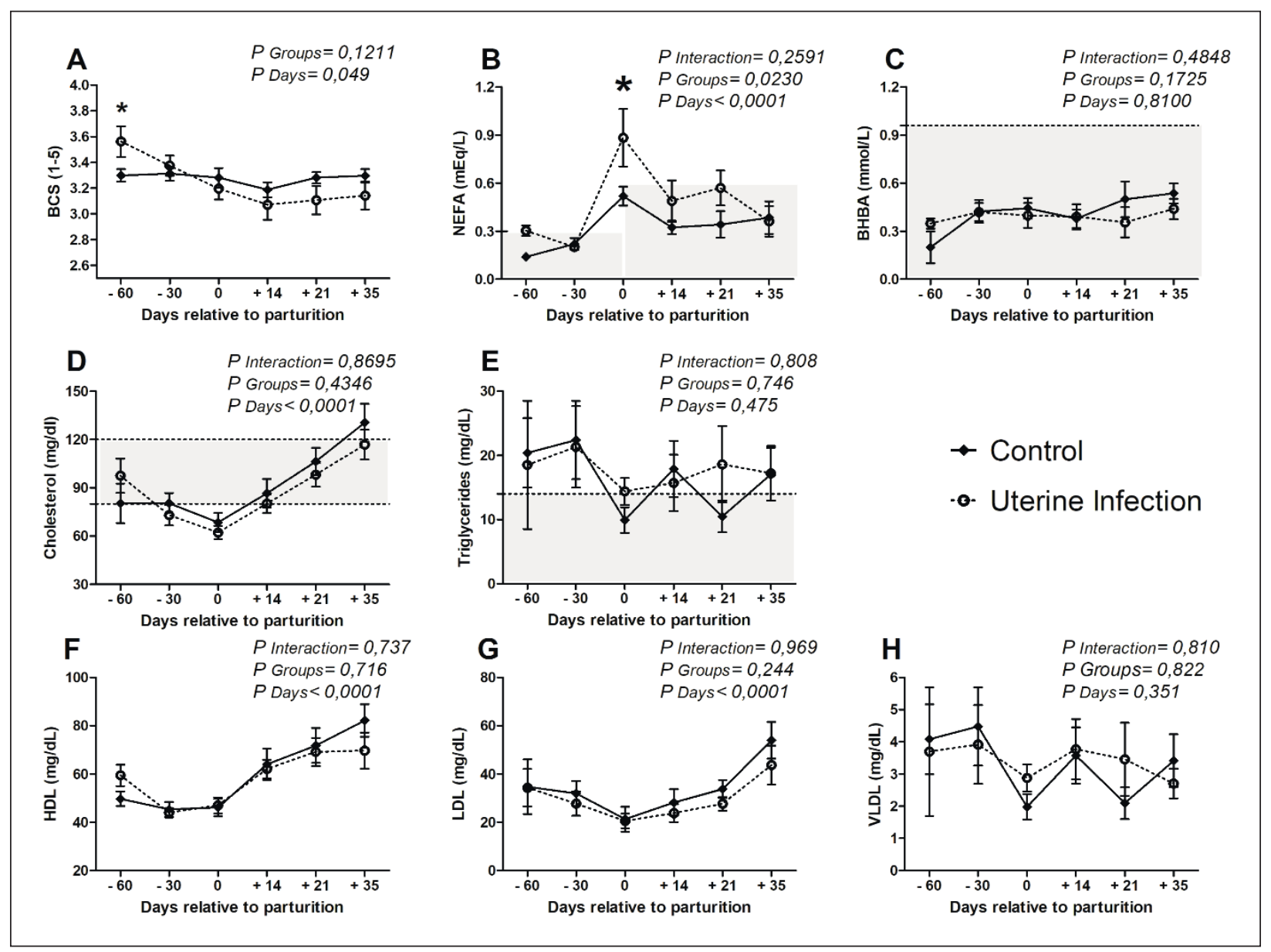

Note: $*$ indicates that the groups differed according to the evaluated time $(\mathrm{p}<0.05)$. Crossbred dairy cows $($ Holstein/Gir $)$ had an average daily milk yield of $24.5 \mathrm{~kg}$.

Furthermore, the serum concentrations of total protein, albumin, and globulins showed no variation between infected or healthy females, at all measured times (Figures 2 A-C). No changes in serum GGT and AST concentrations were found for any of the groups in the peripartum (Figures $2 \mathrm{D}-\mathrm{E}$ ); neither was observed any difference in the levels of the muscle enzyme CK, but with a large dispersion within groups (Figure 2F). 
Figure 2. Protein and enzymatic profile of crossbred dairy cows (Holstein/Gir), with or without uterine diseases, under an intensive production system, Uberlandia - Minas Gerais State, Brazil.

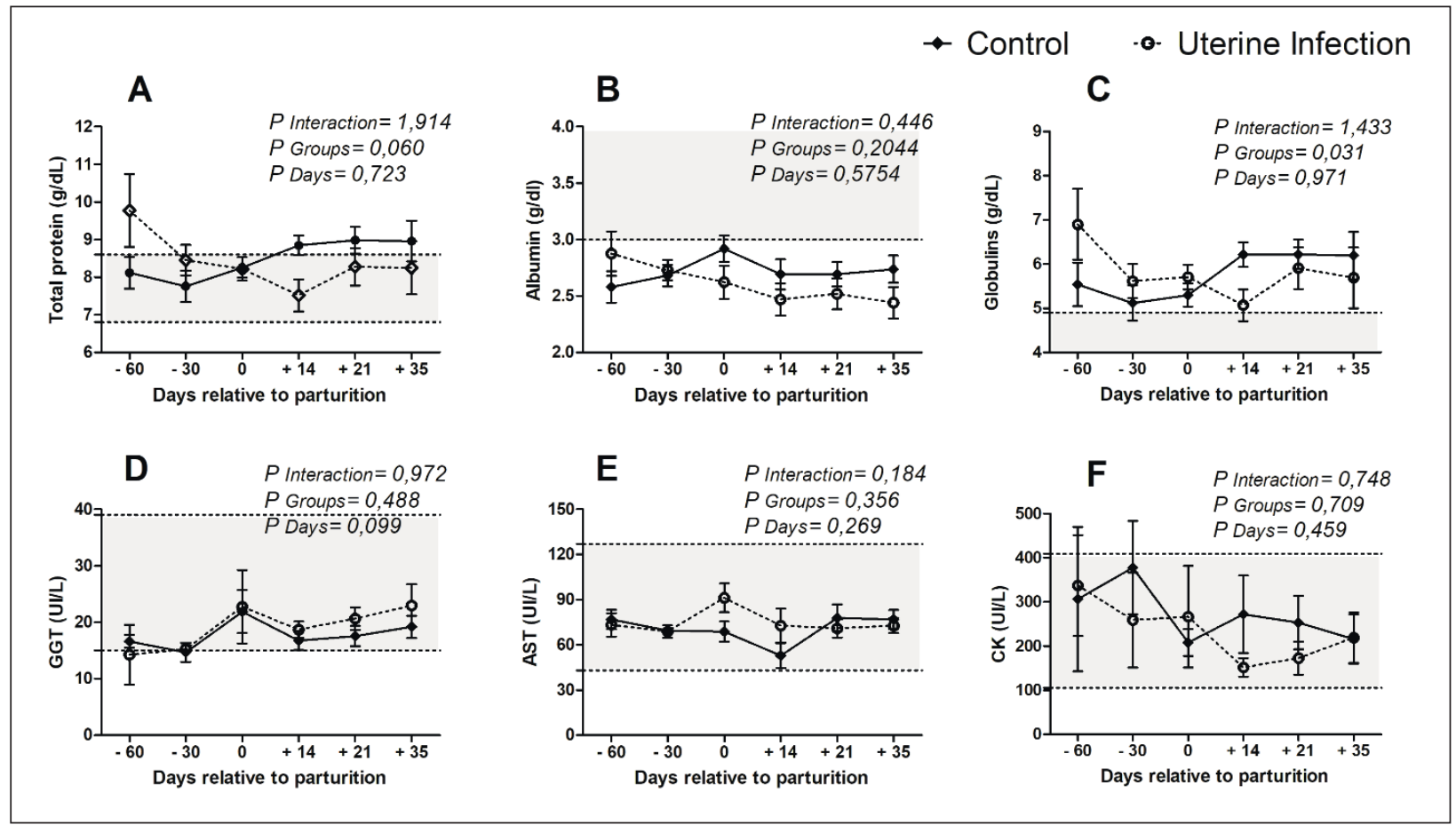

Note: * indicates that the groups differed according to the evaluated time $(\mathrm{P}<0.05)$. Crossbred dairy cows $($ Holstein/Gir $)$ had an average daily milk yield of $24.5 \mathrm{Kg}$.

Concerning the mineral metabolism (Figure averages of infected cows $(5.9 \pm 2.5 \mathrm{mg}$ dL- 1$)$ were 3 A-C), only the serum calcium concentrations lower than were those of the healthy animals $(8.5 \pm$ varied significantly between groups at calving. The $\left.1.0 \mathrm{mg} \mathrm{dL}^{-1}\right)$.

Figure 3. Mineral profile of crossbred dairy cows (Holstein/Gir), with or without uterine diseases, under an intensive production system, Uberlandia - Minas Gerais State, Brazil.

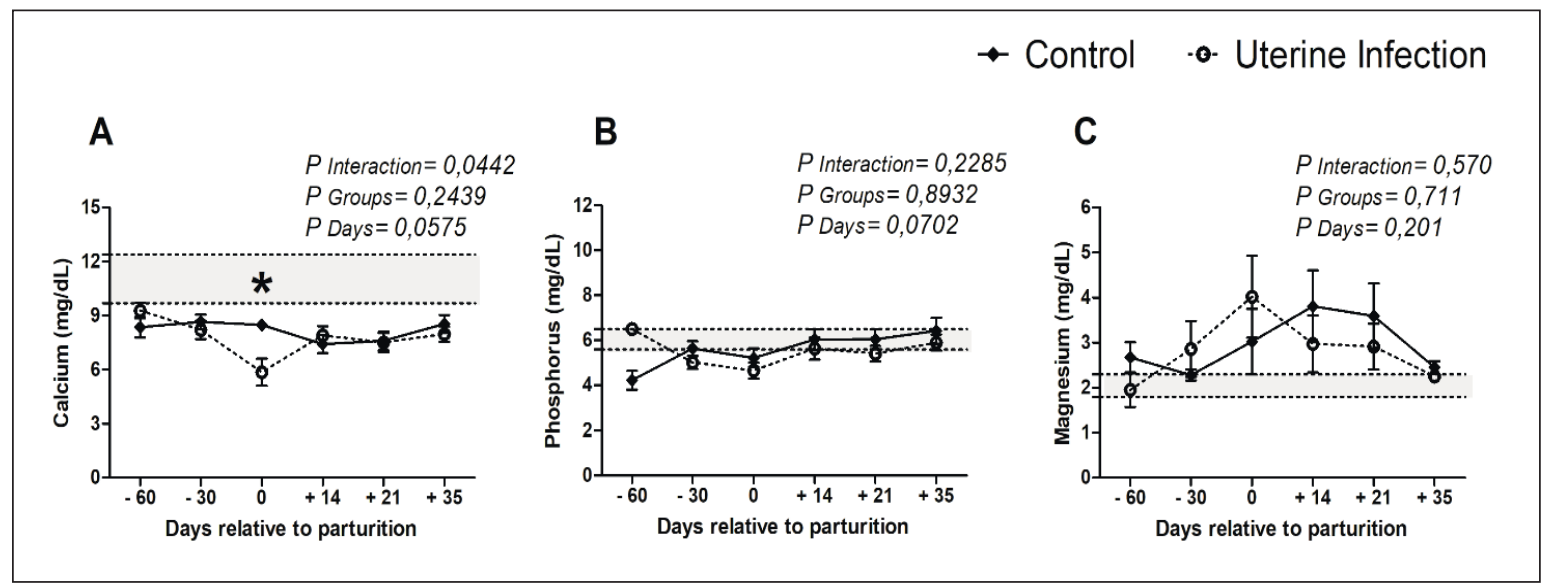

Note: * indicates that the groups differed according to the evaluated time $(\mathrm{P}<0.05)$. Crossbred dairy cows $($ Holstein/Gir $)$ had an average daily milk yield of $24.5 \mathrm{~kg}$. 


\section{Discussion}

The incidence of uterine diseases $(41.2 \%)$ found here, within which $5.9 \%$ for placental retention, $20.6 \%$ for metritis, $11.8 \%$ for clinical endometritis, and $32.3 \%$ for subclinical endometritis, was similar to the finding of Sheldon et al. (2009). These authors reported that between 20 and $40 \%$ of the dairy cows developed metritis, which persisted in $20 \%$ of the animals as clinical endometritis, and in $30 \%$ as subclinical endometritis. According to McDougall et al. (2007) and Gautam et al. (2009), the incidence of uterine disorders tends to decrease because of a spontaneous recovery during the puerperium.

In face of the results found here, dairy cows start to mobilize their body reserves of energy at the time of parturition, and the NEB is evidenced by an elevation in the serum levels of NEFA, besides of less oxidation of fats without significant increase of ketone bodies (BHBA). Although not as expressive as already observed in Holstein cows (RUEGG; MILTON, 1995; LAGO et al., 2001; RENNÓ et al., 2006), the NEB was observed in $35.3 \%$ of the evaluated cows. These results corroborate those of Rennó et al. (2006) and Freitas Júnior et al. (2008), who observed the poor ability of Holstein-Zebu crossbred cows to mobilize body reserves and their lower milk production capacity if compared to Holstein purebred cows.

The average concentrations of NEFA for uterineinfected cows at calving $\left(0.88 \pm 0.65 \mathrm{mEq} \mathrm{L}^{-1}\right)$ were higher than the value proposed by Ospina et al. (2010) (0.6 mEq L-1). This high concentration may be a risk factor, associated with greater chances of developing diseases such as placental retention, metritis, abomasal displacement, and ketosis. Moreover, these high serum levels of NEFA, which determined the presence of NEB in this study, could impair neutrophil activity and uterine health (HAMMON et al., 2006). The inter-relationship between metabolic, endocrine, and immune systems decreases immune competence at the time of parturition, thereby increasing susceptibility to infections (STOFKOVA, 2009) and placental retention (GONÇALVES; KOZICKI, 1997).

This relationship between metabolic changes in the peripartum, especially NEB, and predisposition to postpartum diseases has been reported frequently in Holstein cows (SHELDON; DOBSON, 2004; SPEARS; WEISS, 2008). Higher concentrations of NEFA before and after parturition in Holstein cows are related to the greater occurrence of diseases during the transition period, besides being a risk factor for the health of cows after calving (OSPINA et al., 2010; CHAPINAL et al., 2011; ROBERTS et al., 2012). Animals with intense and prolonged NEB may develop clinical problems, reduced milk yield, and low fertility (DUFFIELD; LEBLANC, 2009).

At calving, the NEB, expressively in infected cows, was preceded by a higher lipomobilization in animals with higher BCS at 60 days before calving, associated with a sharp drop in BCS. The cholesterol levels in crossbred dairy cows showed the same pattern as that already noted in Holstein cows (CAVESTANY et al., 2005; STENGÄRDE et al., 2008; DORLAND et al., 2009; ALVARENGA et al., 2015). Some factors such as food intake reduction and cortisol increase with subsequent cholesterol synthesis decrease can justify the decline in serum levels near parturition (ALVARENGA et al., 2015). No relationship could be detected between the concentrations of cholesterol, triglycerides, and lipoproteins with the presence of puerperal uterine diseases, corroborating the results described in the literature (KANKOFER et al., 1996; OLIVEIRA et al., 2014).

At the peripartum period, both groups presented lower averages of serum calcium and higher ones of serum magnesium if compared to the reference values proposed by Smith (2009). The same author suggested that, at calving, distinct levels of calcium between groups should be considered as relevant for the occurrence of uterine disorders. This is because calcium has a fundamental role in 
muscle contraction and immune responses (GOFF, 2008), thus being important for the activation and chemotaxis of defense cells (GOFF; HORST, 1997; GALVÃO; SANTOS, 2014).

\section{Conclusion}

We concluded that the occurrence of uterine diseases in crossbred cows (Holstein/Gir) can be related to the body condition score (BCS) during the prepartum period, and to serum NEFA and calcium concentrations at parturition.

\section{Acknowledgments}

We acknowledge the Fundação de Amparo à Pesquisa do Estado de Minas Gerais - FAPEMIG (CVZ-APQ-01371-13), the Conselho Nacional de Desenvolvimento Cientifico e Tecnológico - CNPq, and the Coordenação de Aperfeiçoamento de Pessoal de Nivel Superior - CAPES for financial support and granted scholarships. We also thank the team of laboratory technicians and resident veterinary who assisted the biochemical analyses, as well as the owners of the Fazenda Tropical Genética.

\section{References}

ACCORSI, P.; GOVONI, N.; GAIANI, R.; PEZZI, C.; SEREN, E.; TAMANINI, C. Leptin, GH, PRL, insulin and metabolic parameters throughout the dry period and lactation in dairy cows. Reproduction in Domestic Animals, Berlin, v. 40, n. 3, p. 217-223, jun. 2005.

ALVARENGA, E. A.; MOREIRA, G. H. F. A.; FACURY FILHO, E. J.; LEME, F. O. P.; MOLINA, L. R.; LIMA, J. A. M.; CARVALHO, A. U. Avaliação do perfil metabólico de vacas da raça holandesa durante o período de transição. Pesquisa Veterinária Brasileira, Seropédica, v. 35, n. 3, p. 281-290, 2015.

CAMPOS, R.; GONZÁLEZ, F. H. D.; COLDEBELLA, A.; LACERDA, L. de A. Indicadores do controle endócrino em vacas leiteiras de alta produção e sua relação com a composição do leite. Acta Scientiae Veterinariae, Porto Alegre, v. 33, n. 2, p. 147-153, 2005.
CAVESTANY, D.; BLANC, J. E.; KULCSAR, M.; URIARTE, G.; CHILIBROSTE, P.; MEIKLE, A.; FEBEL, H.; FERRARIS, A.; KRALL, E. Studies of the transition cow under a pasture-based milk production system: Metabolic profiles. Journal of Veterinary Medicine, London, v. 52, n. 1, p. 1-7, 2005.

CHAPINAL, N.; CARSON, M.; DUFFIELD, T.; CAPEL, M.; GODDEN, S.; OVERTON, M.; SANTOS, J.; LEBLANC, S. The association of serum metabolites with clinical disease during the transition period. Journal of Dairy Science, Champaign, v. 94, n. 1, p. 4897-4903, 2011.

CHAPINAL, N.; LEBLANC, S. J.; CARSON, M. E.; LESLIE, K. E.; GODDEN, S.; CAPEL, M.; SANTOS, J. E. P.; OVERTON, M. W.; DUFFIELD, T. F. Herdlevel association of serum metabolites in the transition period with disease, milk production, and early lactation reproductive performance. Journal of Dairy Science, Champaign, v. 95, n. 1, p. 5676-5682, 2012.

DORLAND, H. A.; RICHTER, S.; MOREL, I.; DOHERR, M. G.; CASTRO, N.; BRUCKMAIER, R. M. Variation in hepatic regulation of metabolism during the dry period and in early lactation in dairy cows. Journal of Dairy Science, Champaign, v. 92, n. 5, p. 1924-1940, 2009.

DRACKLEY, J. K. Biology of dairy cows during the transition period: the final frontier? Journal of Dairy Science, Champaign, v. 82, n. 11, p. 2259-2273, 1999.

DUBUC, J.; DUFFIELD, T. F.; LESLIE, K. E.; WALTON, J. S.; LEBLANC, S. J. Risk factors for postpartum uterine diseases in dairy cows. Journal of Dairy Science, Champaign, v. 93, n. 1, p. 5764-5771, 2010.

DUFFIELD, T. F.; LEBLANC, S. J. Interpretation of serum metabolic parameters around the transition period. Southwest Nutrition and Management Conference, Chandler, v. 1, n. 1, p. 106-114, 2009.

EDMONSON, A. J.; LEAN, I. J.; WEAVER, L. D.; FARVER, T.; WEBSTER, G. A Body condition scoring chart for holstein dairy cows. Journal of Dairy Science, Champaign, v. 72, n. 1, p. 68-78, 1989.

FACÓ, O.; LÔBOM, R. N. B.; MARTINS FILHO, R.; MOURA, A. A. A. Analysis of productive performance of different holstein $\mathrm{x}$ gir genetic groups in Brazil. Revista Brasileira de Zootecnia, Viçosa, MG, v. 31, n. 5, p. 1944-1952, 2002.

FERREIRA, A. D. M. Reprodução da fêmea bovina: fisiologia aplicada e problemas mais comuns (causas e tratamentos). Juiz de Fora: Edição do Autor, 2010. 420 p. 
FREITAS JÚNIOR, J. E.; ROCHA JÚNIOR, V. R.; NENNÓ, F. P.; MELLO, M. T. P.; CARVALHO, A. P.; CALDEIRA, L. A. Effect of body condition score at calving on productive performance of crossbred Holstein-Zebu cows. Revista Brasileira de Zootecnia, Viçosa, MG, v. 37, n. 1, p. 116-121, 2008.

FRIEDEWALD, W. T.; LEVY, R. I.; FREDRICKSON, D. S. Estimation of the concentration of low-density lipoprotein cholesterol in plasma, without use of the preparative ultracentrifuge. Clinical Chemistry, Washington, v. 18, n. 6, p. 499-502, jun. 1972.

GALVÃO, K. N.; SANTOS, J. E. P. Recent advances in the immunology and uterine microbiology of healthy cows and cows that develop uterine disease. Turkish Journal of Veterinary and Animal Sciences, Ankara, v. 38, n. 1, p. 557-588, 2014.

GAUTAM, G.; NAKAO, T.; YUSUF, M.; KOIKE, K. Prevalence of endometritis during the postpartum period and its impact on subsequent reproductive performance in two Japanese dairy herds. Animal Reproduction Science, Amsterdam, v. 116, n. 3, p. 175-187, 2009.

GOFF, J. P. The monitoring, prevention, and treatment of milk fever and subclinical hypocalcemia in dairy cows. The Veterinary Journal, London, v. 176, n. 1, p. 50-57, 2008.

GOFF, J. P.; HORST, R. L. Physiological changes at parturition and their relationship to metabolic disorders. Journal of Dairy Science, Champaign, v. 80, n. 7, p. 1260-1268, 1997.

GONÇALVES, D.; KOZICKI, L. E. Perfis bioquímicos e imunológicos no período peripartal de vacas leiteiras com e sem retenção de placenta. Brazilian Journal of Veterinary Research and animal Science, São Paulo, v. 34, n. 6, p. 364-370, 1997.

HAMMON, D. S.; EVJEN, I. M.; DHIMAN, T. R.; GOFF, J. P.; WALTERS, J. L. Neutrophil function and energy status in Holstein cows with uterine health disorders. Veterinary Immunology and Immunopathology, Philadelphia, v. 113, n. 1, p. 21-26, 2006.

JUCHEM, S. O.; SANTOS, F. A. P.; IMAIZUMI, H.; PIRES, A. V.; BARNABÉ, E. C. Production and blood parameters of holstein cows treated prepartum with sodium monensin or propylene glycol. Journal of Dairy Science, Champaign, v. 87, n. 3, p. 680-689, 2004.

KANKOFER, M.; WIERCIÑSKI, J.; KÊDZIERSKI, W.; MIERZYÑSKI, R. The analysis of fatty acid content and phospholipase A2 activity in placenta of cows with and without retained fetal membranes. Zentralblatt für Veterinärmedizin. Reihe A, Philadelphia, v. 43, n. 8, p. 459-465, 1996.
KASIMANICKAM, R.; DUFFIELD, T. F.; FOSTER, R. A.; GARTLEY, C. J.; LESLIE, K. E.; WALTON, J. S.; JOHNSON, W. H. Endometrial cytology and ultrasonography for the detection of subclinical endometritis in postpartum dairy cows. Theriogenology, Philadelphia, v. 62, n. 1, p. 9-23, 2004.

KIMURA, K.; GOFF, J. P.; KEHRLI, M. E.; REINHARDT, T. A. Decreased neutrophil function as a cause of retained placenta in dairy cattle. Journal of Dairy Science, Champaign, v. 85, n. 3, p. 544-550, 2002.

KÖPPEN, W. Climatologia: con un estúdio de los climas de la tierra. Buenos Aires: Fondo de Cultura Economica, $1948.478 \mathrm{p}$.

LACETERA, N.; SCALIA, D.; BERNABUCCI, U.; RONCHI, B.; PIRAZZI, D.; NARDONE, A. Lymphocyte functions in overconditioned cows around parturition. Journal of Dairy Science, Champaign, v. 88, n. 6, p. 2010-2016, 2005.

LAGO, E. P.; PIRES, A. V.; SUSIN, I.; FARIAS, V. P. de; LAGO, L. A. do. Effect of body condition score at calving on energy metabolism, milk yield and disease occurence in postpartum of dairy cows. Revista Brasileira de Zootecnia, Viçosa, MG, v. 30, n. 5, p. 1544-1549, 2001.

LEBLANC, S. J.; LISSEMORE, K. D.; KELTON, D. F.; DUFFIELD, T. F.; LESLIE, K. E. Major advances in disease prevention in dairy cattle. Journal of Dairy Science, Champaign, v. 89, n. 1, p. 1267-1279, 2006.

MCDOUGALL, S.; MACAULAY, R.; COMPTON, C. Association between endometritis diagnoses using a novel intravaginal device and reproductive performance in dairy cattle. Animal Reproduction Science, Amsterdam, v. 99, n. 1-2, p. 9-23, 2007.

NOVAES, P. L.; PIRES, M. D. F. Á.; CAMPOS, A. T. Procedimentos para o manejo correto da vaca gestante, no pré-parto, ao parto e pós-parto. Coronel Pacheco: Texto técnico Embrapa Gado de Leite, 2003. 20 p. Disponível em: <https://www.agencia.cnptia.embrapa. br/recursos/Manejo_de_VacasID-fS00ee88ar. pdf $>$. Acesso em: 21 ago. 2015.

OLIVEIRA, R. S. B. R.; MOURA, A. R. F.; PÁDUA, M. F. S.; BARBON, I. M.; SILVA, M. E. M.; SANTOS, R. M.; MUNDIM, A. V.; SAUT, J. P. E. Metabolic profile in crossbred dairy cows with low body condition score in the peripartum period. Pesquisa Veterinária Brasileira, Seropédica, v. 34, n. 4, p. 362-368, 2014.

OSPINA, P. A.; NYDAM, D. V.; STOKOL, T.; OVERTON, T. R. Evaluation of nonesterified fatty acids and beta-hydroxybutyrate in transition dairy cattle in the northeastern United States: critical thresholds for prediction of clinical diseases. Journal of Dairy Science, 
Champaign, v. 93, n. 2, p. 546-554, 2010.

RENNÓ, F. P.; PEREIRA, J. C.; SANTOS, A. D. F.; ALVES, N. G.; TORRES, C. A. A.; RENNÓ, L. N.; BALBINOT, P. Z. Effects of body condition at calving on milk yield and composition, lactation curve and body reserve mobilization of Holstein cows. Arquivo Brasileiro de Medicina Veterinária e Zootecnia, Belo Horizonte, v. 58, n. 2, p. 220-233, 2006.

ROBERTS, T.; CHAPINAL, N.; LEBLANC, S.; KELTON, D.; DUBUC, J.; DUFFIELD, T. Metabolic parameters in transition cows as indicators for earlylactation culling risk. Journal of Dairy Science, Champaign, v. 95, n. 1, p. 3057-3063, 2012.

RUEGG, P. L.; MILTON, R. L. Body condition scores of Holstein Cows on Prince Edward Island, Canada: relationships with yield, reproductive performance, and disease. Journal of Dairy Science, Champaign, v. 78, n. 3, p. 552-564, mar. 1995.

SHELDON, I. M.; CRONIN, J.; GOETZE, L.; DONOFRIO, G.; SCHUBERTH, H. J. Defining postpartum uterine disease and the mechanisms of infection and immunity in the female reproductive tract in cattle. Biology of Reproduction, Oxford, v. 81, n. 1, p. 1025-1032, 2009.

SHELDON, I. M.; DOBSON, H. Postpartum uterine health in cattle. Animal Reproduction Science, Amsterdam, v. 82, n. 83, p. 295-306, 2004.
SHELDON, I. M.; LEWIS, G. S.; LEBLANC, S.; GILBERT, R. O. Defining postpartum uterine disease in cattle. Theriogenology, Philadelphia, v. 65, n. 8, p. 15161530, 2006.

SMITH, B. P. Large animal internal medicine. $4^{\text {th }}$ ed. St. Louis: Mosby Elsevier, 2009. 1712 p.

SPEARS, J. W.; WEISS, W. P. Role of antioxidants and trace elements in health and immunity of transition dairy cows. The Veterinary Journal, London, v. 176, n. 1, p. 70-76, 2008.

STENGÄRDE, L; TRÅVÉN, M.; EMANUELSON, U.; HOLTENIUS, K.; HULTGREN, J.; NISKANEN, R. Metabolic profiles in five high-producing Swedish dairy herds with a history of abomasal displacement and ketosis. Acta Veterinaria Scandinavica, London, v. 50, n. 1, p. 1-11, 2008.

STOFKOVA, A. Leptin and adiponectin: from energy and metabolic dysbalance to inflammation and autoimmunity. Endocrine regulations, Bratislava, v. 43, n. 4, p. 157-168, out. 2009.

WILLIAMS, E. J.; FISCHER, D. P.; PFEIFFER, D. U.; ENGLAND, G. C. W.; NOAKES, D. E.; DOBSON, H.; SHELDON, I. M. Clinical evaluation of postpartum vaginal mucus reflects uterine bacterial infection and the immune response in cattle. Theriogenology, Philadelphia, v. 63 , n. 1, p. 102-117, 2005. 
